\title{
A Decommodified Experience? Exploring Aesthetic, Economic and Ethical Values for Volunteer Ecotourism in Costa Rica
}

\author{
Noella J. Gray and Lisa M. Campbell \\ Nicholas School of the Environment and Earth Sciences, Duke University, \\ Marine Lab Road, Beaufort, North Carolina, USA
}

\begin{abstract}
Volunteer ecotourism has been described as an 'ideal' form of decommodified ecotourism that overcomes problems associated with tourism in general, and ecotourism specifically. Using a case study of volunteer ecotourism and sea turtle conservation in Costa Rica, this paper interrogates this ideal. Perceptions of volunteer ecotourism were explored through in-depth interviews with 36 stakeholders, including hosts, NGO staff, government employees, local 'cabineros' (families who provide accommodation) and guests (volunteers). Results show that while all stakeholder groups share similarly positive views of volunteer ecotourism, subtle but important differences exist. We analyse these differences in terms of aesthetic, economic, and ethical values, and situate the results in existing theories about the moralisation and decommodification of ecotourism.
\end{abstract}

doi: $10.2167 / j o s t 725.0$

Keywords: Costa Rica, decommodified, ecotourism, non-governmental organisation (NGO), sea turtle, volunteer tourism

\section{Introduction}

This paper explores the aesthetic, economic and ethical values associated with volunteer ecotourism, and how volunteer tourism can be understood in terms of current thinking about moralising and decommodifying processes in ecotourism. Volunteer tourism is a type of alternative tourism in which tourists 'volunteer in an organised way to undertake holidays that might involve aiding or alleviating the material poverty of some groups in society, the restoration of certain environments or research into aspects of society or environment' (Wearing, 2001: 1). Volunteer tourism has experienced significant growth since the 1970s (Ellis, 2003; Wearing, 2004). The size of the volunteer tourism market and its growth rate are difficult to ascertain, although the recent proliferation of volunteer tourism organisations and programmes suggests that the sector is substantial and increasing (Brown \& Morrison, 2003). When volunteers work on environmental conservation or research projects, volunteer tourism can overlap substantially with ecotourism (Ellis, 2003; see for example Campbell \& Smith, 2005; Duffy, 2002; Wearing, 2001). While there are other forms of volunteer tourism, environmental volunteering is a popular option. For example, the Earthwatch Institute has sent more than 72,000 paying 
volunteers on scientific research expeditions since its founding in 1971 (Earthwatch Institute, 2005). As of 2001, 71\% of their trips were focussed on life sciences research, capitalising on volunteers' interest in wildlife and ecology (Ellis, 2003).

In addition to organisations such as Earthwatch, countless opportunities are available through environmental non-governmental organisations (NGOs). In the case of sea turtle conservation, a particularly popular form of volunteer ecotourism (Ellis, 2003), numerous volunteer opportunities are regularly available throughout Africa, Asia and Latin America (see job list on www.seaturtle.org). NGOs have been one of the main sources of support for ecotourism development more generally (Honey, 1999), so it is perhaps not surprising that they have also become one of the main providers of ecotourism experiences (Wearing et al., 2005). Volunteers provide much needed labour and financial support for conservation projects (Ellis, 2003; Halpenny \& Caissie, 2003; Ryan et al., 2001; Wearing, 2004), while environmental NGOs offer eco-minded travellers an alternative to mainstream tourism experiences (Duffy, 2002). Duffy has argued that 'conservation volunteer movements are a significant force in the development of ecotourism in the South' (Duffy, 2002: 68).

Despite the suggested importance of volunteer tourism in the growth of ecotourism, academic interest in volunteer tourism is fairly recent (Stoddart \& Rogerson, 2004; Wearing, 2001) and research remains scant, focussed primarily on the identities, behaviours, values, motives and personal development of the volunteers (Broad, 2003; Campbell \& Smith, 2005, 2006; Halpenny \& Caissie, 2003; McGehee, 2002, 2005; Stoddart \& Rogerson, 2004; Wearing, 2001). While it is important to understand volunteers, they represent only one half of the story, and 'understanding the phenomenon of volunteering in tourism should take into account both the demand and the supply sides of this industry' (Uriely et al., 2003: 61). While Uriely et al. (2003) call specifically for consideration of volunteer hosts, we would expand the analysis to all actors involved in volunteer tourism, whether or not they are involved as volunteers. Like Uriely et al. (2003) and Clifton and Benson (2006), we seek to expand the research agenda by turning outwards to look at the broader social meaning of volunteer tourism.

The purpose of this paper is to examine how both hosts and guests construct meanings of volunteer ecotourism in the context of an NGO-managed volunteer ecotourism and sea turtle conservation project in Costa Rica. Specifically, we consider the importance of aesthetics, economics and ethical values to these meanings, and in how constructed meanings can be understood in terms of debates about moralising and decommodifying processes in ecotourism (Butcher, 2006; Wearing et al., 2005). Given the potential for volunteer ecotourism to fulfil the criteria of 'ideal' ecotourism (Wearing, 2001), its promotion as an appropriate type of tourism for isolated communities in developing areas (Clifton \& Benson, 2006; Jackiewicz, 2005), the conflicting evidence of both its positive effects (Broad, 2003; Clifton \& Benson, 2006; Wearing, 2001) and problems (Duffy, 2002), its contribution to the overall growth of ecotourism (Duffy, 2002), and the debate over whether it represents a decommodified (Wearing et al., 2005) or development-limiting paradigm (Butcher, 2006), it warrants further attention. 


\section{Volunteer Ecotourism}

There is no commonly accepted definition of ecotourism (Ross \& Wall, 1999; Weaver, 2001). According to Blamey (1997), this definitional confusion arises from debates over whether such definitions should be focussed on demand or supply, concerned with intentions or outcomes, and perhaps most importantly (given our focus on values), whether they should be descriptive or normative. Blamey (2001) argues that ecotourism has evolved from a strictly descriptive term focussed on the nature-based element of the tourist experience to a normative concept, with ecotourism including environmental education and striving towards sustainable management, primarily in the form of continued support for both conservation and local economies. Honey (1999), for example, argues that ecotourism should include: travel to a 'natural' destination, relatively low visitor impacts, environmental education for both tourists and local people, support for conservation, benefits for and involvement of the local population, and a respect for local culture and rights. These characteristics are also evident in one of the more frequently cited definitions of ecotourism: 'responsible travel to natural areas that conserves the environment and sustains the wellbeing of local people' (TIES, 2004).

Ecotourism is part of the broader category of alternative tourism, which arose in the 1980s and 1990s partially in response to the negative impacts of mass tourism (Mowforth \& Munt, 1998). The rise of alternative tourism represented a 'shift in focus from the wellbeing of the tourist industry to the wellbeing of the host community' (Weaver, 1998: 31). It has also been promoted as a morally superior alternative to mass tourism, one that allows tourists and the tourism industry to alleviate rather than contribute to local environmental and economic woes (Butcher, 2003). Volunteer tourists are the quintessential 'new moral tourists' (Butcher, 2003), as their role in fulfilling local needs is explicitly highlighted by both the volunteers themselves and the companies that market volunteer tourism experiences (Simpson, 2004).

While early views of ecotourism and other forms of alternative tourism were largely benevolent (Munt, 1994), more critical discussions have since emerged. Rather than acting as a panacea for local conservation and development challenges, ecotourism development has had mixed results in practice (e.g. Doan, 2000; Orams, 2002; Weaver, 2001; Weinberg et al., 2002), often exacerbating local inequalities and political tensions (Belsky, 1999; Stonich, 1998; Young, 1999). Although such critiques are important, the focus in this paper is on complementary analyses of the meanings and values associated with ecotourism.

Smith and Duffy (2003) identify three values associated with tourism (aesthetic, economic and ethical), all of which have been interrogated in the context of ecotourism. Although critical examination of these and related values extends well beyond tourism, our focus here is on how they have been understood in relation to ecotourism and volunteer tourism specifically. For a discussion of environmental values more generally, for example, see Kellert (1993) and Rolston (1988). Aesthetically, ecotourism has been critiqued as representing a privileging of Western environmental values and science (Akama, 1996) or 'green imperialism' (Mowforth \& Munt, 1998), as host destinations are required to supply and comply with tourists' expectations of an Edenic nature. Ecotourism destinations must exemplify 'Nature', 'Exotic' and/or 'Simple' (West \& Carrier, 2004: 491). 
These constructs of 'nature' and 'local people' are then subjected to visual consumption via the tourist gaze (Mowforth \& Munt, 1998; Ryan et al., 2000; Urry, 1995); ecotourism may actually be characterised more by aesthetic consumption than by education or conservation (Ryan et al., 2000). Economically, the global push for ecotourism development enforces a 'postneoliberal environmentaleconomic paradigm' that requires developing countries to 'sell nature to save it' (McAfee, 1999). Several authors (e.g. Duffy, 2002; McAfee, 1999; West \& Carrier, 2004) have questioned whether ecotourism is any better than mass tourism when it continues to reinforce exploitative capitalist relations. Ethically, the superiority of ecotourism has also been questioned based on the behaviour of the tourists. Duffy (2002), who calls it 'green greed', and Munt (1994), who terms it 'ego-tourism', both argue that tourists' 'selfless' contributions to local communities and environments are actually self-serving attempts to build their own cultural capital. All of these critiques amount to an indictment of ecotourism as the commodification of people and places for the aesthetic consumption of self-indulgent tourists. In this view, volunteer ecotourism can be understood as a form of alternative consumption; consumption is the 'new' activism, a way for individuals to 'make a difference' (Bryant \& Goodman, 2004). Like 'the tourist' (MacCannell, 1976), the volunteer ecotourist seeks to build identity through consumption; her desire for authentic interaction with other cultures (and natures), however sincere, is obscured by the commodification of the interaction.

In contrast to this critical view of ecotourism, Wearing $(2001,2004)$ describes volunteer ecotourism as a bright alternative that promotes host selfdetermination, local control, sustainability, environmental stewardship and the privileging of local culture and values. For Wearing (2001), the true test of a volunteer tourism project is whether or not it moves beyond the typical, commodified tourism experience to a level of genuine exchange between hosts and guests (i.e. volunteers). He proposes that volunteer tourism projects can be positioned along a continuum from commodified (least desirable; resembles typical mass tourism) to decommodified (most desirable; benefits for and involvement of local residents, communication of local views and practices to volunteers), and identifies his case study of the Youth Challenge International volunteer programme in Costa Rica as an ideal form of decommodified volunteer tourism. This 'ideal' designation was attributed to the extensive interaction between volunteers, local residents and the environment, the involvement of and benefits to the local community, and the conservation ethic underlying the programme. However, Wearing's analysis is based primarily on volunteers' views and does not explicitly account for host experiences with the programme. Also problematic is Wearing's notion of 'genuine exchange', which neither problematises the underlying notion of 'authenticity' nor recognises the inequality inherent in situations where hosts are the recipients of volunteers' charity.

Using the case study of Gandoca, Costa Rica, this paper will examine how all actors actively involved with a volunteer ecotourism project conceptualise it. How do they define and characterise volunteer ecotourism? How do they perceive volunteer ecotourism as a means of pursuing conservation and local development objectives? Is volunteer ecotourism perceived as fulfilling the criteria of 'ideal' ecotourism? How do actors articulate aesthetic, economic and 
ethical values in describing the elements of volunteer tourism in Gandoca? Addressing these questions will allow us to further assess the role of volunteer tourism in upholding and/or challenging the decommodification and moralisation processes associated with ecotourism.

\section{Ecotourism in Gandoca, Costa Rica}

Gandoca is a community of approximately 100 people located on the southeast coast of Costa Rica, and is adjacent to the Gandoca-Manzanillo National Wildlife Refuge. Established by the Costa Rican government in 1985, the refuge covers both marine and land areas, and includes sea grass beds, coral reef, mangrove swamp, rainforest and nesting beaches for endangered leatherback, green and hawksbill sea turtles, all of which serve as attractions for ecotourists (ANAI, n.d., 2002a; SINAC, 2002). The Ministry of Environment and Energy (MINAE) has a local office in Gandoca, and is legally responsible for managing the refuge.

Asociación ANAI, a Costa Rican NGO, has been working in Gandoca since 1978 (ANAI, n.d.). Its mission is to 'help the people of Talamanca [region of Costa Rica] design and implement a strategy linking socio-economic development, cultural strengthening and biodiversity conservation' (ANAI, 2002a). Most of the funding for the organisation comes from foreign donors, including bilateral aid agencies and larger NGOs (ANAI, n.d., 2002a). Although it has diverse funding sources, ANAI obtains grants and loans on a project-by-project basis and, like many other NGOs, is constantly searching for funding to support its programmes.

In 1985, ANAI began the Sea Turtle Conservation Project to help protect the three species of sea turtle that nest on Gandoca beach (ANAI, 2001). Initially this project entailed beach patrols by one ANAI staff member. In 1990, the Sea Turtle Conservation Project incorporated two new elements: formal research activities and a volunteer programme (ANAI, 2002b). The project's research and volunteer activities extend from the beginning of March until the end of July, the duration of the leatherback turtle nesting season (leatherbacks are the most frequently sighted species locally). In 2001, a total of 303 volunteers came over during this five month period, each staying for an average of 19 nights (ANAI, 2001). Approximately two-thirds of these volunteers were women and onethird men, and the majority were from Europe (52\%) or North America (33\%) (ANAI, 2001). This project tends to attract young travellers (often students) on a small budget, similar to other volunteer research ecotourism projects (Clifton \& Benson, 2006; Galley \& Clifton, 2004) and in contrast to the 'typical' older, affluent ecotourist reported by some authors (e.g. Fennell, 2002; Hvenegaard \& Dearden, 1998).

Volunteers are responsible for assisting with monitoring turtle nest hatcheries, patrolling the beach at night and recording measurements of nesting turtles, among other activities (ANAI, 2002b). In 2002, the project employed five local research assistants (all males between the ages of 17 and 23) and six unpaid international research assistants to lead volunteer groups and coordinate their work. In addition, the project employs several local residents as support staff. Volunteers stay with local families, who provide room and board; these 
families (or cabineros) have formed an association and are collectively responsible for managing the volunteers' lodging. In 2002, volunteers paid a registration fee of US\$25 to ANAI and \$14 per day for room and board directly to the host family. The vast majority of foreign visitors to Gandoca come to volunteer with ANAI, and the main economic activity in Gandoca is the volunteer ecotourism generated by the ANAI Sea Turtle Conservation Project. Thus the guests in this case are the volunteer ecotourists while the hosts (i.e. actors directly engaged with the supply side of volunteer ecotourism in Gandoca) are ANAI, the cabineros and the MINAE park guards. All of the cabineros and half of the ANAI staff are from Gandoca; the MINAE park guards are from other villages in Costa Rica (within the same region), while the remaining ANAI staff are from San Jose or other Latin American countries.

\section{Study Methods}

This research employs a qualitative, case study approach. Qualitative methods are ideally suited to answering questions about the meanings, interpretations and explanations people associate with particular phenomena (Seale, 1999), while a case study is appropriate for investigation of phenomena, such as volunteer ecotourism, that are rooted in specific spatial and temporal contexts (Lofland \& Lofland, 1995). Tourism consists of a mélange of meanings (Ryan et al., 2000) that are actively constructed by actors in discourse. Like McCabe and Stokoe, we use interviews to 'reveal the sense-making procedures displayed in talk' (McCabe \& Stokoe, 2004: 605). A total of 36 in-depth, semi-structured interviews were conducted from June to August 2002, in conjunction with participant observation. The lead author lived in Gandoca for approximately three months, during which time she boarded with a cabinero family, interacted daily with two of the local ANAI employees who lived in the same house and participated in both community and volunteer social activities. While data presented in this paper are derived from interviews, daily interactions with all actors provided additional context for the interviews and informed the overall argument.

For interviewing, purposeful sampling was used to identify research participants that presented 'information-rich cases' (Patton, 1990: 169). These included: 10 ANAI staff members (interviews A1 to A10), two locally based employees of MINAE (interviews M1 and M2), 15 volunteers (interviews V1 to V15), one regional ecotourism network coordinator (interview $\mathrm{O} 1$ ) and 11 cabineros from the eight cabinero families (interviews $\mathrm{C} 1$ to $\mathrm{C} 8$ ). In three of the cabinero interviews (C1, C6 and C7), two members of the cabinero family participated in interviews, but one member of each pair dominated the discussion in all cases. Thus, these interviews are treated as a single respondent. With respect to ANAI, MINAE and the cabineros, sampling was exhaustive; except for three local ANAI research assistants who declined to participate in the research, all of the MINAE staff, cabinero families, and relevant ANAI staff were interviewed. In the case of the volunteers, the 15 interviewed were chosen based on (1) an established social rapport with the researcher, which generally enables interviews and improves the respondent's candour (Duffy, 2002) and (2) a minimum stay in Gandoca of at least one week, preferably more. Volunteer interviews were undertaken over a two-month period so that the sample 
included both mid-season volunteers (who saw many turtles) and end-of-season volunteers (who often did not see any turtles). Although the views of local residents who are not directly engaged with volunteer tourism also contribute to the mélange of meanings, their views are not included here. The focus instead is on hosts who have substantial involvement with the volunteers.

Interviews ranged from 40 minutes to 2 hours. An interview guide was used to prompt respondents to discuss certain topics, including (but not limited to) positive and negative aspects of the volunteer experience and the ANAI project, similarities and differences between volunteers and other tourists, and positive and negative aspects of tourism and tourism development, both generally and in Gandoca. All interviews were conducted in either English or Spanish, tape recorded and later transcribed. Interview transcripts were analysed using a constructivist grounded-theory approach, in which emergent themes are viewed as the result of a particular interaction between the researcher and research participants (following Charmaz, 2002). In contrast to an objectivist approach that sees data as reflective of an external reality, a constructivist approach seeks to interpret the social world, rather than provide 'an exact picture of it' (Charmaz, 2002: 678). Grounded theory is also useful when there is little existing theory in a subject area, a situation true for studies of volunteer ecotourism. Themes were identified both inductively (based on categories and ideas presented by interviewees) and deductively (based on categories and ideas implied in interview questions or present in the academic literature). In keeping with the grounded theory approach, results are organised around these key themes, with extracts from interviews presented to illustrate the links between data and analysis (following Charmaz, 2001). Verbatim quotes serve either as typical examples of, or exceptions to, central themes (see Ryan \& Bernard, 2000), and were selected based on how well they communicate the central idea of a theme as well as an attempt to include multiple voices from all actor groups. The first results section focusses on volunteers' accounts of their experiences, while subsequent sections include the views of all actors interviewed.

\section{Characterising the Volunteer Experience}

When asked to describe their experience in Gandoca or to comment on the ANAI Sea Turtle Conservation Project, volunteers $(n=15)$ offered a range of responses. Positive aspects included: interaction with sea turtles; social interaction with both volunteers and local residents; helping with conservation; cultural/language exchange; education, and relaxation. Negative aspects included: feeling unneeded or 'used'; struggling with the language barrier; physical hardship (insects, lack of sleep, physical exertion); not seeing turtles, and lack of activities/amenities. Although volunteers generally emphasised positive aspects of the experience, two of the negative aspects, 'feeling unneeded/used' and 'not seeing turtles', are worth examining in detail for what they tell us about aesthetic values.

In 2002, there were many volunteers present in July, at the end of the turtle nesting season. Several volunteers did not see any turtles during their stay and mentioned in interviews that they felt unneeded, that their presence was not vital to the conservation work, and that there was not enough for them to do. 
For some volunteers the key issue was seeing a turtle (an aesthetic experience). 'If you came here just because you wanted to see the place, you would be very happy with it, but the point is that I came to see the turtles, and if you haven't seen them then you go back. .. not quite happy' (V10). For others it was a matter of feeling that their presence was necessary for the conservation work. 'I don't feel like I've really been helping personally, which is somewhat of a disappointment. . . Of course I want to see one [a turtle], but I don't think it's necessary... If I was the only other person here and they needed me for patrol, and I didn't see one turtle, that would be enough. Just to know that I needed to be there' (V9). Seeing turtles and fulfilling the need to help with conservation are clearly important aspects of the ANAI volunteer experience, influencing the tone and content of volunteers' views of other aspects of the project. The following sections consider these volunteer views as well as the perceptions of ANAI staff, MINAE staff and the cabineros.

\section{Supporting Conservation and Development}

Unlike tourist operators, the purpose of most environmental NGOs is not the provision of tourist services and experiences. It is thus not surprising that of the 29 respondents who discussed the purpose of the ANAI Sea Turtle Conservation Project, none of them identified tourism specifically. However, if volunteer conservation programmes are a form of ecotourism, then it is interesting to consider what the actors involved in the ANAI project do perceive as the purpose, if not tourism. The conceptualisation of ecotourism in Gandoca is directly related to how the purpose of the ANAI Sea Turtle Project is envisioned.

In establishing the Sea Turtle Conservation Project, the aim of ANAI was to conserve the nesting colonies [of sea turtles] through a collaborative process that would also contribute to an improvement in the quality of human life in Gandoca' (ANAI, 2002a). The research respondents echoed these objectives, identifying conservation, research and community benefits as the project's three purposes. Conservation was the most commonly cited purpose, mentioned by 26 of 29 respondents, followed by community benefits (17 of 29) and research (5 of 29). For some ANAI and volunteer respondents, sea turtle conservation was the only purpose they recognised. One volunteer said, 'The purpose is to save the turtles' (V10), while an ANAI staff member observed, 'The purpose is conservation, really. To conserve the species as much as we can' (A4). However, more than half of the respondents also identified the provision of benefits to the community, either as an equally important or secondary purpose of the project. For example, as an ANAI representative said, 'The purpose is the protection of turtles. And all the benefits that the community has have been a direct result of the turtles. The turtles are the central purpose of ANAI, in Gandoca' (A6). In other cases, the provision of community benefits was perceived to be the overriding purpose.

I guess it kind of has two purposes; one is the environmental side of helping an endangered species. For me, what I think is more important is the aspect of helping the community... I get the impression that the project really does help the economy of the community a lot, and they're grateful 
to have it here because it does bring them a lot of money... So I think that both to help the community and the environment. (V3)

For the cabineros, conservation and community benefits were not only equally important, but also inextricably linked. As one cabin owner said, 'The purpose is conservation of the turtle. To bring in money, bring volunteers. To help people help themselves because many people live on the money volunteers bring in' (C1).

\section{Volunteers or Tourists?}

Although the ANAI volunteers can be classified as tourists, it is important to understand how the actors themselves view volunteers in the context of tourism. The 'volunteer tourist' is not a homogenous, unproblematic category, and not all volunteer tourists 'see themselves or are perceived by host organisations and communities, as volunteers and/or tourists' (Lyons, 2003: 5). In this case, respondent views ranged from seeing volunteers as complete tourists to not viewing them as tourists in any way. This range was captured at three points in the analysis: Yes, the volunteer is a tourist (4 of 36); Yes, the volunteer is a special type of tourist (20 of 36), and No, the volunteer is not a tourist (12 of 36). Volunteers were classified as tourists by a greater proportion of the volunteers themselves (11 of 15) than by host respondents (13 of 21), although similar reasons were given by both groups for viewing volunteers as tourists (foreign, pay, travel, special kind of tourist) or not (work, altruism, local involvement). As an actor group, ANAI was most reluctant to classify volunteers as tourists (only four of ten ANAI respondents did so), while the majority of all other actor groups conceded that volunteers are a type of tourist (7 of 8 cabineros, 11 of 15 volunteers, 2 of 2 MINAE staff).

All but one of the interviewees noted that there is a difference between volunteers and (other) tourists. Four differences that were cited by both volunteers and host respondents were work, the altruistic nature of the volunteers, their desire to learn, and their local involvement. In addition, the volunteers mentioned that they had a lesser need for amenities and longer length of stay than other tourists, while the local respondents noted that volunteers tend to spend less money than other tourists and have a smaller impact. Twenty-eight of the respondents mentioned work and/or altruism, highlighting these as ethical values that distinguish volunteers. Some respondents referred to these features as the reason for classifying volunteers as a special kind of tourist. 'My concept of a tourist is anyone who leaves his house for a trip is a tourist. And I think they are volunteer tourists, because they come to help protect the turtles and to leave money in the community' (C6). Others mentioned work or altruism as the basis for removing volunteers from the tourist category altogether.

Tourism is totally different from volunteering. People who go to volunteer, anywhere, they go to work, with love, for something that is being lost, that is disappearing. And the tourists, no, they come to see something they like, and they only come to see the things they like... so it's totally different. (A4) 
Volunteer interviewees categorised volunteering as a special kind of tourism, or as something separate from tourism, based on their own attributes and intentions rather than those of the project. They emphasised their altruism and caring, their interaction with local people, their lesser impacts, their contribution to conservation, their interest in learning, and their lesser need for amenities. This emphasis on volunteers' characteristics was most evident in the responses of four volunteers who noted that even though they classify volunteers as tourists, this classification depends upon whether the primary motivation of the individual volunteer is travel or altruism. As one person said, 'Some people come here to stay for a week to see turtles and stay in a nice place and see a bit of Costa Rica and that sort of thing, but then there are people like [V10] who every single holiday she has she does something to save the world, and I don't think that's quite tourism' (V15).

Although the nuances of individual volunteer motivations may vary, each volunteer serves the same function in terms of providing labour for the ANAI Sea Turtle Conservation Project and income for families in Gandoca. In this sense, volunteers are indeed different from other tourists who might come to the area. As one cabinero said:

Volunteers are students who come to learn from the community, see the system, get to know Costa Rica and they have an interest in caring for the turtles. They are more highly regarded and are charged less. The tourists don't work; they want to see turtles and go, they want to sightsee. They are all tourists but the higher consideration is given to the volunteers working with the project. (C2)

An ANAI respondent also clearly articulated the multiple, inter-related differences between volunteers and other tourists, emphasising both economic and ethical values.

[Volunteers are] very different, as different as different can be. They're different because their vacation is working on something that is of interest to them... Usually tourists are valued in terms of how much money they leave, that's the measure - how many days they stay, and how much they spend per day. The way to value the tourists that go to Gandoca and work on the turtle project or other volunteer projects is a completely different valuation. The amount of money they bring in is important in the general scheme of things, in terms of creating livelihood for local people, but the value that they are putting into the process is huge and it has to do with how they spend their time. (A1)

\section{Recognising Elements of Ecotourism}

Regardless of whether interviewees viewed the purpose of the project as tourism, or were willing to identify volunteers as tourists, all respondents recognised explicitly or implicitly that the ANAI project is a form of ecotourism. Respondents were asked to discuss the positive and negative aspects of the ANAI project and of tourism in Gandoca. In doing so they identified five elements of ecotourism: local economic benefits, support for conservation, environmental 
education, community involvement in the project, and tourism as an alternative to the consumptive use of turtles and their eggs.

The interviewer was careful to avoid using the term 'ecotourism' in interviews, unless the respondent first mentioned it, in order to avoid forcing this label onto respondents' views. Nonetheless, 10 respondents described the project as ecotourism unprompted.

I think it is an advanced form of ecotourism. We pay to do something that we like to do... I'm 100\% in favour of ecotourism, that's why I agreed to pay the money they asked from me. I am coming to work but I don't mind paying because I know it's the way ecotourism works. (V8)

One ANAI interviewee was critical of ecotourism as a label, pointing to its frequent misuse, but indicated that the ANAI Sea Turtle Project is a genuine form of ecotourism. 'Very little ecotourism in any way has anything to do with eco, other than the fact that people go to natural places. It doesn't in any way support eco, and it doesn't support local people. And we wanted to do that, both of those things' (A1). Only one respondent introduced the term ecotourism and then refused to include the ANAI project under this label. This respondent was adamant that volunteers were not tourists, and therefore could not view the ANAI project as a form of ecotourism. He still recognised some of the elements of ecotourism in the project, but chose the label 'sustainable development' in place of ecotourism:

It's sustainable development, it's not ecotourism, because I don't know if it would be the same project if it was ecotourism, if you built a hotel or something. . . I think the project is much better the way it's set up, because it's more long term, it's more personal, for the people who do the volunteer work, it's amazing, because they're just here to have a good time and to protect the turtles. (V12)

Although they did not use the term ecotourism, the remaining 26 respondents still recognised the same key elements of ecotourism. All of the interviewees recognised that the ANAI Sea Turtle Project brings economic benefits to Gandoca. Many respondents repeatedly emphasised both the importance of the project's economic benefits and the link between tourism and conservation. One ANAI respondent underlined the importance of this link by expressing a desire to assign a clear economic value to each sea turtle conserved:

What I would like to see is. . to assign a number to a turtle, how much is it worth. . . So that turtle was seen by 20 volunteers, that was the reason the volunteers were here. How much money does each turtle bring for the community? This number would be important to know, because people understand numbers. (A3)

Although each 'saved' sea turtle may not have an exact price tag attached to it, it is clear that local respondents still appreciate the link between economic benefits from tourism and conservation. One ANAI respondent from Gandoca clearly viewed this relationship very seriously, in spite of responding jokingly: 
In the case that the turtles disappear, all that money will disappear, and if there are no turtles there won't be any volunteers. . . the volunteers come for the turtles. So if there aren't any turtles, why would they come? To see me? I don't think so, I'm not that pretty to look at. (A4)

The income provided by volunteers is one of the few sources of cash income for most of the cabineros, who otherwise rely on some subsistence agriculture and small amounts of income from selling coconuts, cattle, or other agricultural products. Despite the fact that all interviewees were aware of the economic benefits of the project, not all of them identified the provision of local benefits as an actual purpose of the project, as previously discussed. This may be because they supported the notion of integrating conservation with economic development and viewed the ANAI project as an ideal way of doing conservation rather than as ecotourism per se.

In places like Costa Rica, where it is one of the few places left with a lot of natural resources, anything we can do to not deplete them and use them in a more positive manner is good. Because I think it's hard when people say to locals 'you can't cut down these trees even though your children are starving', because if your children are starving you're going to do whatever you can and not worry about the long term effects 100 years from now... this is a way to get both sides, to help the environment and feed the children, to simplify it a lot. (V3)

Other interviewees believed that the economic benefits local residents derive from volunteers indirectly support conservation by providing an alternative to the consumption of turtle eggs, and explicitly describe this as a kind of ecotourism:

The local community seems to get an awful lot out of the project... The financial incentives of this project, over poaching eggs, are much greater. It's also an alternative - it's now a bigger resource than the turtles, so it is an alternative resource... It's good that the money does actually go into the community, quite obviously, and I think there must be a million ecotourism operations where it's somebody who lives a thousand miles away who operates it and gets the money off it, and no one in the area gets anything. (V2 and V15)

While all actors saw economic benefits as a critical component of the project, and some even identified it as a primary purpose, volunteers were also critical of (or concerned about) the importance placed on economic benefits by local people. For example, some respondents perceived the motivations of local residents to be based entirely (or almost entirely) on money: 'I think turtles are their cash cow... there's definitely money behind it all' (V6). These volunteers were concerned that if there were no economic benefits from the project, the local residents would no longer support turtle conservation.

I would say [their motivation is] money. I don't think it's a conservation issue. If they're interested in conservation it's because they want to 
preserve the project as a money making scheme... if the money wasn't there they may return to their old way of poaching. (V1)

Other volunteers hoped that local residents were motivated by environmental as well as economic concerns:

If they have a passion for the turtles because they're worried about their survival then that's going to... filter down through the community to the kids, generation after generation. However, if it's just a means to an end financially, then without the policing of it. . . it's likely they will collect eggs again. I think you hope that they're doing it for a bit of both. (V2)

One volunteer was less concerned about the possibility of residents returning to the consumption of turtles and their eggs in the future, believing that local residents had developed support for turtle conservation by economically benefiting from the project:

People are going to make choices that benefit them economically. People need to make a living, that's just the way it is. . . So I guess through economics, or through the benefits that they receive economically, then they start to see that it's a great resource and they need to protect it. And I think they feel glad that they're doing both. (V12)

At the root of volunteers' perceptions and concerns regarding economic motivations seemed to be their views of local environmental values. Most interviewees had very positive impressions of local residents, characterising them as friendly and hospitable; none of the respondents reported strong negative views of local people. However, several of them were still concerned with what they perceived as a lack of local environmental awareness:

I find it sad that people in the community here just get the money but don't really get involved more deeply and they are not really becoming conscious of the importance of what is going on here... I'm not sure if a person here has seen a turtle, and that's a bit shocking, isn't it? They've received volunteers for 15 years, they can see that people travel from all over the world to come here and see that, and they never make efforts to go to the beach on patrol and see turtles... If the project had to stop, I'm not sure if the local community is conscious enough to carry on saving the turtle... In Gandoca, definitely, people need to learn much, much more [about] their environment. (V8)

In the views of these volunteers, it is not sufficient that local residents no longer consume turtle eggs; in addition to realising an economic benefit in the conservation of sea turtles, local people should acquire an environmental consciousness mirroring that of the volunteers.

\section{Views of Tourism Development}

Respondents' views of tourism development in Gandoca further added to their visions of ecotourism. When asked to discuss the issue of development, and to reflect on what they would like to see happen in Gandoca over the 
next five to ten years, respondents were unanimous in their opposition to mass tourism development in the area. Seven of 34 respondents (five volunteers, two hosts) favoured the other extreme, suggesting that Gandoca should stay 'as is':

I'd like it to stay the way it is, I wouldn't really want any more tourism development, because you would have hotels and restaurants and things like that. Yeah, I'd like to see it stay as it is. . any more tourists here, and I don't think it would help the turtles. If I came back in 5 years time and saw hotels and stuff like that I'd be pretty disappointed. (V7)

An ANAI staff member concurred: 'I wouldn't like to see it more civilized, to see more roads built on natural land to facilitate tourism. . I'm against that. I understand people need to have easier access, but a balance needs to be found. I would prefer it to remain the way it is' (A8).

The remaining respondents (10 volunteers, 17 local people) supported minimal, controlled development in Gandoca. However, there was some variation among the actors in their main concerns for tourism development. The volunteer respondents focussed primarily on environmental impacts; it was this concern for the environment, not local incomes, which informed their views.

Yeah, I think it [tourism development] would be fine. As long as it doesn't interrupt too much the environment around here or the beach and all that. . Right now the turtles don't seem to mind, but I don't think hundreds of people should be going back and forth on the beach, so maybe a little bit of development but not masses. (V11)

Both the ANAI and MINAE respondents also mentioned a concern for preventing negative environmental impacts; several of them expressed support for an increase in economic benefits and maintenance of local control as well. The cabineros, on the other hand, were clearly most concerned with increasing the economic benefits of tourism and emphasised the importance of maintaining local ownership and control of tourism:

In the future, let's say if a foreigner comes here and builds cabins, what will the people in Gandoca do? They will suffer, because a person with a lot of money will build nice cabins, and the tourists will go to the nice cabins. But that's what I don't want to happen here. In the future, I think it will be possible to build nice cabins, to attract more tourists, and that the same people from the community should be the owners of the cabins, not foreigners. (C4)

Thus, although there initially appears to be broad agreement over views of tourism development, there is actually an important difference between the cabineros and the other actors. For the cabineros, tourism development should be carefully controlled in order to ensure that economic benefits accrue to local people, not outsiders, and to prevent unwanted social impacts. For the volunteers, ANAI and MINAE, carefully controlled tourism development is more about controlling and minimising environmental impacts and only secondarily about ensuring local control (if at all). 


\section{Conclusion}

At first glance, volunteer ecotourism appears to offer the potential for 'ideal' ecotourism. It may prove to be a viable strategy in rural developing areas where other livelihood opportunities are limited, tourism can be locally controlled and benefits locally distributed, and environmental experiences provided for volunteers without infringing on local rights. As tourism continues to expand its reach, volunteer tourism may indeed be the strategy of choice for rural communities in developing areas (Clifton \& Benson, 2006; Jackiewicz, 2005). Our results suggest widespread support for volunteer ecotourism among all actor groups who are directly involved in the ANAI Sea Turtle Conservation Project. In spite of this support, our research questions the extent to which volunteer ecotourism is inherently different from other forms of ecotourism with regard to aesthetic, economic and ethical values. Below, we discuss how these values play out in Gandoca, in order to contribute to current thinking about the moralisation (Butcher, 2003) and decommodification (Wearing, 2001; Wearing et al., 2005; Wearing \& Wearing, 1999) of ecotourism.

First, while some volunteers clearly want the aesthetic experience of witnessing a turtle on Gandoca beach (and are disappointed if they do not see a turtle), they also put strong emphasis on a lived experience. Ideally, this lived experience implies working with (and thus seeing) turtles, but at the minimum involves feeling involved and useful. The emphasis on interaction also resurfaces when volunteers distinguish what they do (i.e. work) from what other tourists do (i.e. see), a distinction that is generally agreed upon by all actors involved in volunteer ecotourism in Gandoca. Wearing and Wearing (1999) suggest that this interaction with, rather than consumption of, environment is a sign of decommodification, but this may be oversimplified. For example, volunteer ecotourists have extremely high expectations for interactions with wildlife (Campbell \& Smith, 2006; Weiler \& Richins, 1995), and Campbell and Smith (2006) suggest that when such interactions occur, they enhance the overall aesthetics of the experience. Thus, the separation of 'doing' and 'seeing' may not be straightforward. There is also an aesthetic of ecotourism in Gandoca that is unrelated to nesting sea turtles, and that concerns how actors envision future tourism development. Volunteers want to see Gandoca stay as is (in the words of one volunteer, 'I wouldn't want to see it more civilised') or with very minimal development. In this way, volunteers express an aesthetic that requires a 'development freeze' for local people, a criticism of the ecotourism aesthetic in general (Butcher, 2003; Mowforth \& Munt, 1998; Scheyvens, 1999; Urry, 1995; West \& Carrier, 2004).

Second, all actors are aware of the economic benefits of volunteer ecotourism in Gandoca, and emphasise that these benefits are retained locally. Both ANAI and the cabineros note that volunteers spend less money than regular tourists, but this is accepted (and even promoted) because the volunteers do work and because the money is spent on locally owned accommodation. One prerequisite for decommodification, according to Wearing (2001), is that the profits from ecotourism are directed towards the local community rather than outside companies; in this sense, the decommodification of volunteer ecotourism in Gandoca is highlighted by all actor groups. However, Wearing (2001) also argues that a decommodified experience involves genuine exchange between hosts and 
guests, an exchange that can be questioned based on volunteer perceptions of economic benefits. While MINAE, ANAI and the cabineros are unanimous in their support for local economic benefits, volunteers are somewhat ambivalent. On the one hand, they recognise the importance of providing economic incentives for environmental protection to local people, and many see this as an important, if not the most important, aspect of the project. This view reflects the discourse of 'green developmentalism'; that nature must pay its way is accepted by all actors (the ANAI respondent's desire to put a dollar value on each turtle is perhaps the clearest example of such thinking). On the other hand, volunteers are critical of the way they perceive local people to prioritise economic outcomes in the absence of greater environmental awareness or appreciation for turtles. In this way, volunteers reflect the Western environmental values identified by Akama (1996) and the 'green imperialism' critiqued by Mowforth \& Munt (1998); that local people value sea turtles economically may not be enough to satisfy volunteers. Volunteers want to see their own values for sea turtles spread among local people, undermining Wearing's argument that volunteer ecotourism privileges local values and enables 'genuine exchange'.

Conflicting views of economic value by cabineros versus volunteers/ANAI/MINAE are also evident, as local people emphasise economic benefits when envisioning future development, while other actors emphasise environmental impacts. This reflects Butcher's (2003) critique of 'the New Moral Tourism' as characterising local people and environments as overly fragile and sensitive to impacts, thereby serving to restrict benefits as much as prevent harm. 'From this perspective it is as least as true to argue that the problem is not too much development, but too little, and perhaps not too many tourists, but too few' (Butcher, 2003: 61). Although such differences in priorities may not be surprising, they also reinforce West and Carrier's (2004) argument regarding the necessity that nature and local inhabitants be 'simple' in ecotourism, an issue discussed above as the ecotourism aesthetic; while aesthetics may not be the exclusive driver of any development freeze in Gandoca, concerns for nesting sea turtles or wider environmental quality by volunteers, ANAI and MINAE may achieve the same result. Given increasing tourism development along the Caribbean coast of Costa Rica in general, the potential conflict of values is more than an academic concern.

Third, ethical values are implicated in much of the deliberation about whether or not the ANAI project is ecotourism, or volunteers are ecotourists. All actors claim aspects of ecotourism for the project (whether or not they do so explicitly), in accordance with the key themes of ecotourism outlined by Honey (1999). However, actors are in conflict about whether or not the project is ecotourism. This conflict can be understood as part of the 'moralisation of tourism' (Butcher, 2003). If interviewees see all tourism as bad, they must position the ANAI project as different from tourism in order to support it. Thus, volunteers are not tourists. If actors see tourism as bad, but ecotourism as good (i.e. 'The New Moral Tourism', Butcher, 2003), then the project can be safely categorised as ecotourism, and volunteers as ecotourists. In this view, tourism as an activity can be 'rescued', i.e. decommodified, although it is important to note that local respondents may want it to be more commodified than do other actors (e.g. they want the money from tourists and a certain amount of tourism development). 
Either way, traditional forms of tourism are cast as 'bad', reflecting the evolution of normative definitions of ecotourism as well as the rise of alternative consumption. Of all actors, ANAI staff were most resistant to categorise volunteers as tourists, a resistance shared by another NGO in Costa Rica that runs a volunteer programme: 'Make no mistake, this is no "eco-tour"!' (Caribbean Conservation Corporation, 2003). While these distinctions are likely to be an attempt to distance NGOs from critiques of tourism and ecotourism in Costa Rica and elsewhere, they may also serve the pragmatic purpose of lowering volunteer expectations regarding on-site amenities.

As discussed in the introduction, Wearing (Wearing, 2001; Wearing \& Wearing, 1999) proposes a commodification continuum on which volunteer ecotourism projects (or just ecotourism projects) may be placed, depending upon the aesthetic, economic and ethical values supported. At one end, tourism is commodified; it resembles mass tourism, economic values equate to profits accrued by non-local companies, local environments and people are aesthetically consumed, and tourists neither question these values nor seek to demonstrate more ethical values. At the opposite end, tourism is decommodified; economic benefits are locally retained, tourists engage in meaningful experiences with local environments and people, and they seek such 'ethical' engagement with local culture rather than the enhancement of their own 'cultural capital'. In the case of Gandoca there is evidence that actors identify with both commodification and decommodification, hedonism and altruism; the ANAI project undoubtedly exists somewhere along Wearing's spectrum rather than at one extreme or the other. Perhaps more importantly, there is also evidence that different actors would place the ANAI project at different places along this continuum, in part because they have different ideas and priorities with respect to conservation and development. Underlying the decommodification spectrum there remains an assumption that conservation and development can fit together in a 'winwin' scenario, an assumption that may not hold when multiple perspectives are considered. It is not a matter of measuring 'the' decommodification of a volunteer ecotourism project, but of understanding the multiple meanings attached to a project by individuals with different interests and power. The question remains, for example, whether volunteer tourism represents decommodification or merely an alternative (ethical) commodity culture (Bryant \& Goodman, 2004). Furthermore, only the hosts (i.e. actors directly involved in ecotourism in Gandoca) have been considered in this analysis. Other local residents not involved with ecotourism would add to the mélange of meanings associated with volunteer tourism in Gandoca.

Overall there are still too few studies of volunteer ecotourism, especially those that examine volunteer and other actor views, to generalise; this raises the question of where future research should be focussed. One possible line of inquiry is the comparison of meanings, perceptions of impacts, and measured impacts, especially in terms of Wearing's framework of decommodification. If impacts are to be planned for and mitigated (if negative) or enhanced (if positive) in order to sustain volunteer ecotourism projects over the long term, then an uncritical assumption that volunteer tourism is inherently special and different from other forms of ecotourism will likely prove to be problematic. Altruistic intention may not necessarily translate into greater economic or lesser 
environmental or cultural impacts. Assumptions about the moralisation of volunteer ecotourism can also be better interrogated by considering meanings and impacts in combination. Depending on how such research progresses, definitions of volunteer ecotourism may need to account for outcomes as well as intentions.

\section{Acknowledgements}

The research for this article was funded by the Social Sciences and Humanities Research Council (SSHRC) of Canada. We would like to thank the staff of Asociación ANAI and MINAE, ANAI volunteers and the residents of Gandoca for their participation in this research, as well as Z. Meletis, three anonymous reviewers and the editors who provided valuable comments on an earlier version of the paper.

\section{Correspondence}

Any correspondence should be directed to Noella Gray, Nicholas School of the Environment and Earth Sciences, Duke University Marine Laboratory, 135 Duke Marine Lab Road, Beaufort, North Carolina 28516, USA (njg3@duke.edu).

\section{References}

Akama, J. (1996) Western environmental values and nature-based tourism in Kenya. Tourism Management 17, 567-574.

ANAI (2001) Project Report: Sea Turtle Conservation Project on the Southern Caribbean Coast, Talamanca, Costa Rica, San Jose, Costa Rica.

ANAI (2002a) Homepage of Asociación ANAI. http://www.anaicr.org. Accessed 02.04.07.

ANAI (2002b) Volunteer Manual: Sea Turtle Conservation Program. Talamanca, Costa Rica.

ANAI (n.d.) Asociación ANAI: A Closer Look, San Jose, Costa Rica.

Belsky, J. (1999) Misrepresenting communities: The politics of community-based rural ecotourism in Gales Point Manatee, Belize.Rural Sociology 64, 641-666.

Blamey, R.K.(1997) Ecotourism: The search for an operational definition. Journal of Sustainable Tourism 5, 109-130.

Blamey, R.K. (2001) Principles of ecotourism. In D. Weaver (ed.) The Encyclopedia of Ecotourism (pp. 5-22). New York: CAB International.

Broad, S. (2003) Living the Thai life - a case study of volunteer tourism at the Gibbon Rehabilitation Project, Thailand. Tourism Recreation Research 28, 63-72.

Brown, S. and Morrison, A.M. (2003) Expanding volunteer vacation participation: An exploratory study on the mini-mission concept. Tourism Recreation Research 28, 73-82.

Bryant, R.L. and Goodman, M. K. (2004) Consuming narratives: The political ecology of 'alternative' consumption. Transactions of the Institute of British Geographers 29, 344-366.

Butcher, J. (2003) The Moralisation of Tourism: Sun, Sand. . . and Saving the World? New York: Routledge.

Butcher, J. (2006) A response to building a decommodified research paradigm in tourism: The contribution of NGOs, by Stephen Wearing, Matthew McDonald and Jess Ponting. Journal of Sustainable Tourism 14, 307-310.

Campbell, L.M. and Smith, C. (2005) Volunteering for sea turtles? Characteristics and motives of volunteers working with the Caribbean Conservation Corporation in Tortuguero, Costa Rica. MAST 3\&4, 169-194.

Campbell, L.M. and Smith, C. (2006) What makes them pay? Values of volunteer tourists working for sea turtle conservation. Environmental Management 38, 84-98.

Caribbean Conservation Corporation (2003) CCC's research participant volunteer programs. http:/ /www.cccturtle.org/program.htm. Accessed 25.02.05. 
Charmaz, K. (2001) Grounded theory. In R. Emerson (ed.) Contemporary Field Research: Perspectives and Formulations (pp. 335-352). Prospect Heights, IL: Waveland Press.

Charmaz, K. (2002) Qualitative interviewing and grounded theory analysis. In J. Gubrium and J. Holstein (eds) Handbook of Interview Research (pp. 675-694). London: Sage.

Clifton, J. and Benson, A. (2006) Planning for sustainable ecotourism: The case for research ecotourism in developing country destinations. Journal of Sustainable Tourism 14, 238 254.

Doan, T. (2000) The effects of ecotourism in developing nations: An analysis of case studies. Journal of Sustainable Tourism 8, 288-304.

Duffy, R. (2002) A Trip Too Far: Ecotourism, Politics and Exploitation. London: Earthscan.

Earthwatch Institute (2005) Earthwatch Institute fact sheet. http://www. earthwatch.org/pubaffairs/facts.html. Accessed 08.04.05.

Ellis, C. (2003) Participatory environmental research in tourism: A global view. Tourism Recreation Research 28, 45-55.

Fennell, D. (2002) The Canadian ecotourist in Costa Rica: Ten years down the road. International Journal of Sustainable Development 5, 282-299.

Galley, G. and Clifton, J. (2004) The motivational and demographic characteristics of research ecotourists: Operation Wallacea volunteers in South-east Sulawesi, Indonesia. Journal of Ecotourism 3, 69-82.

Halpenny, E. and Caissie, L. (2003) Volunteering on nature conservation projects: Volunteer experience, attitudes and values. Tourism Recreation Research 28, 25-33.

Honey, M. (1999) Ecotourism and Sustainable Development: Who Owns Paradise? Washington, D.C.: Island Press.

Hvenegaard, G. and Dearden, P. (1998) Ecotourism versus tourism in a Thai National Park. Annals of Tourism Research 25, 700-720.

Jackiewicz, E. (2005) Tourism without threat? Excerpts from rural Costa Rica. Annals of Tourism Research 32, 266-268.

Kellert, S.R. (1993) Attitudes, knowledge, and behavior toward wildlife among the industrial superpowers - United-States, Japan, and Germany. Journal of Social Issues 49 (1), 53-69.

Lofland, J. and Lofland, L. (1995) Analyzing Social Settings: A Guide to Qualitative Observation and Analysis. Belmont, CA: Wadsworth Publishing Company.

Lyons, K. (2003) Ambiguities in volunteer tourism: A case study of Australians participating in a J-1 visitor exchange program. Tourism Recreation Research 28, 5-13.

MacCannell, D. (1976) The Tourist: A New Theory of the Leisure Class. New York: Schocken Books.

McAfee, K. (1999) Selling nature to save it? Biodiversity and green developmentalism. Environment and Planning D: Society and Space 17, 133-154.

McCabe, S. and Stokoe, E.H. (2004) Place and identity in tourists' accounts. Annals of Tourism Research 31, 601-622.

McGehee, N. G. (2002) Alternative tourism and social movements. Annals of Tourism Research 29, 124-143.

McGehee, N. G. (2005) Social change, discourse, and volunteer tourism. Annals of Tourism Research 32, 760-779.

Mowforth, M. and Munt, I. (1998) Tourism and Sustainability: New Tourism in the Third World. London: Routledge.

Munt, I. (1994) Eco-tourism or ego-tourism? Race and Class 36, 49-60.

Orams, M. (2002) Marine ecotourism as a potential agent for sustainable development in Kaikoura, New Zealand. International Journal of Sustainable Development 5, 338-352.

Patton, M. (1990) Qualitative Evaluation and Research Methods. London: Sage.

Rolston, H.I. (1988) Environmental Ethics: Duties to and Values in the Natural World. Philadelphia: Temple University Press.

Ross, S. and Wall, G. (1999) Ecotourism: Towards congruence between theory and practice. Tourism Management 20, 123-132.

Ryan, C., Hughes, K. and Chirgwin, S. (2000) The gaze, spectacle and ecotourism. Annals of Tourism Research 27, 148-163.

Ryan, G. and Bernard, H.R. (2000) Data management and analysis methods. In N. Denzin and Y. Lincoln (eds) Handbook of Qualitative Research (pp. 769-801). London: Sage. 
Ryan, R., Kaplan, R. and Grese, R. (2001) Predicting volunteer commitment in environmental stewardship programmes. Journal of Environmental Planning and Management 44, 629-648.

Scheyvens, R. (1999) Ecotourism and the empowerment of local communities. Tourism Management 20, 245-249.

Seale, C. (1999) The Quality of Qualitative Research. London: Sage.

Simpson, K. (2004) 'Doing development': The gap year, volunteer-tourists and a popular practice of development. Journal of International Development 16, 681-692.

Sistema Nacional de Areas de Conservación (SINAC) (2002) Refugio Nacional de Vida Silvestre Gandoca-Manzanillo. (Pamphlet).

Smith, M. and Duffy, R. (2003) The Ethics of Tourism Development. London: Routledge.

Stoddart, H. and Rogerson, C. (2004) Volunteer tourism: The case of habitat for humanity South Africa. GeoJournal 60, 311-318.

Stonich, S. (1998) Political ecology of tourism. Annals of Tourism Research 25, 25-54.

The International Ecotourism Society (TIES) (2004) What is ecotourism? http:// www.ecotourism.org/index2.php?what-is-ecotourism. Accessed 08.04.2005.

Uriely, N., Reichel, A. and Ron, A. (2003) Volunteering in tourism: Additional thinking. Tourism Recreation Research 28, 57-62.

Urry, J. (1995) Consuming Places. New York: Routledge.

Wearing, S. (2001) Volunteer Tourism: Experiences That Make a Difference. New York: CABI.

Wearing, S. (2004) Examining best practice in volunteer tourism. In R. Stebbins and M. Graham (eds) Volunteering as Leisure/Leisure as Volunteering (pp. 209-224). Cambridge: $\mathrm{CABI}$.

Wearing, S., McDonald, M. and Ponting, J. (2005) Building a decommodified research paradigm in tourism: The contribution of NGOs. Journal of Sustainable Tourism 13, 424-439.

Wearing, S. and Wearing, M. (1999) Decommodifying ecotourism: Rethinking global-local interactions with host communities. Society and Leisure 22, 39-70.

Weaver, D. (1998) Ecotourism in the Less Developed World. New York: CABI.

Weaver, D. (2001) Ecotourism. Sydney: John Wiley and Sons.

Weiler, B. and Richens, H. (1995) Extreme, extravagant and elite: A profile of ecotourists on Earthwatch expeditions. Tourism Recreation Research 20, 29-36.

Weinberg, A., Bellows, S. and Ekster, D. (2002) Sustaining ecotourism: Insights and implications from two successful case studies. Society \& Natural Resources 15, 371-380.

West, P. and Carrier, J.G. (2004) Ecotourism and authenticity: Getting away from it all? Current Anthropology 45, 483-498.

Young, E. (1999) Balancing conservation with development in small-scale fisheries: Is ecotourism an empty promise? Human Ecology 27, 581-620. 